\title{
Assessment and Attainment of Course Outcomes With Scope For Improvement: A Sample Pragmatic Case Study for Incorporating Outcome Based Education in Engineering Colleges
}

\author{
Krishnamoorthy Somasundaram, ${ }^{1, *}$, Balasubramanian Vinoth Kumar $^{2}$, Paulraj Sivakumar ${ }^{3}$ \\ \{sks.it@psgtech.ac.in ${ }^{1}$, bvk.it@psgtech.ac.in ${ }^{2}$,psk.it@psgtech.ac.in $\left.{ }^{3}\right\}$ \\ Assistant Professor (Selection Grade),Department of Information Technology, PSG College of \\ Technology, Coimbatore, Tamil Nadu, India ${ }^{1}$, Associate Professor, Department of Information \\ Technology, PSG College of Technology, Coimbatore, Tamil Nadu, India ${ }^{2}$, Assistant Professor (Senior \\ Grade), Department of Information Technology, PSG College of Technology, Coimbatore, Tamil Nadu, \\ India $^{3}$
}

\begin{abstract}
Machine learning is one of the technologies coming to help the deployment of smart cities in all phases. The diagnosis is a crucial phase that comes to ensure the implementation of a project adapted to the reality of the city diagnosed; this step requires a significant financial commitment. This paper comes to deploy a frugal diagnostic approach of the smart environment component while using self-learning techniques. In addition, assessments are reported and regulatory maturity with respect to this new concept is explored through machine learning. In the near future machine, learning will play a crucial role in the implementation of this kind of concept.
\end{abstract}

Keywords: Natural Language Toolkit; Machine Learning; High performance Computing; Smart governance; Smart cities.

\section{Introduction}

"Education is not the learning of facts, but the training of the mind to think" -Albert Einstein

Education is a deliberate procedure through which an individual gains information, experience, aptitude and demeanor. It makes an individual humanized, refined, refined and instructed. Education today should make a human with social obligation. The genuine motivation behind instruction is to make each human to be a superior people with adoration for oneself, others and for the country. Nowadays, Education should target fabricating general culture of adoration, equity, equity and harmony. It is the light which ought to arouse the fire in anticipation of the experiences of life and to confront any sort of circumstance with certainty. The fortes of education include:

a). Development in knowledge - Makes the person to choose his life. It empowers the individual to more extensive his insight into numerous things that occurs around him and around the globe. It gives both common and otherworldly information. 
b). Illumination - Empowers the individual with numbness to attention to life. It makes the individual to reason out each activity that he does. It edifies the individual with soul reason for his life on earth.

c). Surroundings - Teaches part about condition just as it significance for human better living. Each person is made mindful of the need to deal with the planet that we are living in.

d). Personality Development - makes an individual all-around learned, he turns into an individual with fine characteristics. An individual with fine characteristics makes a best character.

e). Makeover - The education must acquire change in core of the person. It should make an individual to acknowledge with the end goal of his life on this planet. The education must bring change in the person as well as country in general. It should begin with learning.

f). Values in Life - Education does more than just give skilled and experienced people an excellent name in societal structure. However, it also instructs those values as well as how to live a life that is meaningful.

g). Governance - Individual must show esteems forever. Education not just gives a decent name to the individuals who are qualified in the general public. Be that as it may, it instructs those qualities how to make an actual existence definitively lived. Every person is a leader in making for the future.

h). Goal - Instigates each person to have a dream and to move in the direction of his/her prosperity. It offers direction to people to arrive at his objective and achieve his triumph in a simple manner.

i). Wholesome Development - Make an individual completely developed in his stature and in his sensible reasoning. It ought not to be an advancement of scholarly however it ought to turn into a healthy improvement of a person that makes him extraordinary in his life.

National Board of Accreditation (NBA), India provides guidelines for the knowledge, skills and attitudes possessed by graduates from engineering programs. The NBA aims to assess the subjective capability of engineering and technology programmes offered by educational institutions at all levels, from recognition to post-graduate, as well as other related disciplines. NBA appeared as a free independent body with the destinations of confirmation of value and significance to specialized training, particularly of the programs in professional disciplines through the component of accreditation of programs offered by technical institutions. The NBA conducts assessment of programs based on set down standards. This may incorporate, however not constrained to institutional missions and goals, association and administration, foundation offices, nature of instructing and learning, educational program structure and survey, bolster administrations and whatever other angle which will help the graduates produced by the organizations according to industry necessities. Over the course of its existence, the NBA has presented new accreditation procedures, specifications, and standards that are in connection with ideal world - wide strategies and are used to assess the program's outcomes.

Outcome-Based Education (OBE) is a useful hypothesis that bases each component of an educational framework on a set of standards (Outcomes). Every student ought to have accomplished the objective before the finish of the program. There is no single indicated style of instructing or evaluation in OBE; rather, classes, chances, and appraisals should all assist students with accomplishing the predetermined outcomes. OBE accentuates on 
a). Stating what you need your graduate to have the option to do toward the finish of the program,

b). Assessing the graduates whether they can do what they are relied upon to do to do what they are required to do,

c). Familiarizing educating and other scholastic procedures to encourage graduates to do what they are required to do

The earlier content based learning system concentrates on exam and grade driven assessment process where content and deliverables were rigid and non-negotiable as shown in figure 1 . In content based learning system, the emphasis is on what teacher hopes to achieve and content is placed on a rigid frames.

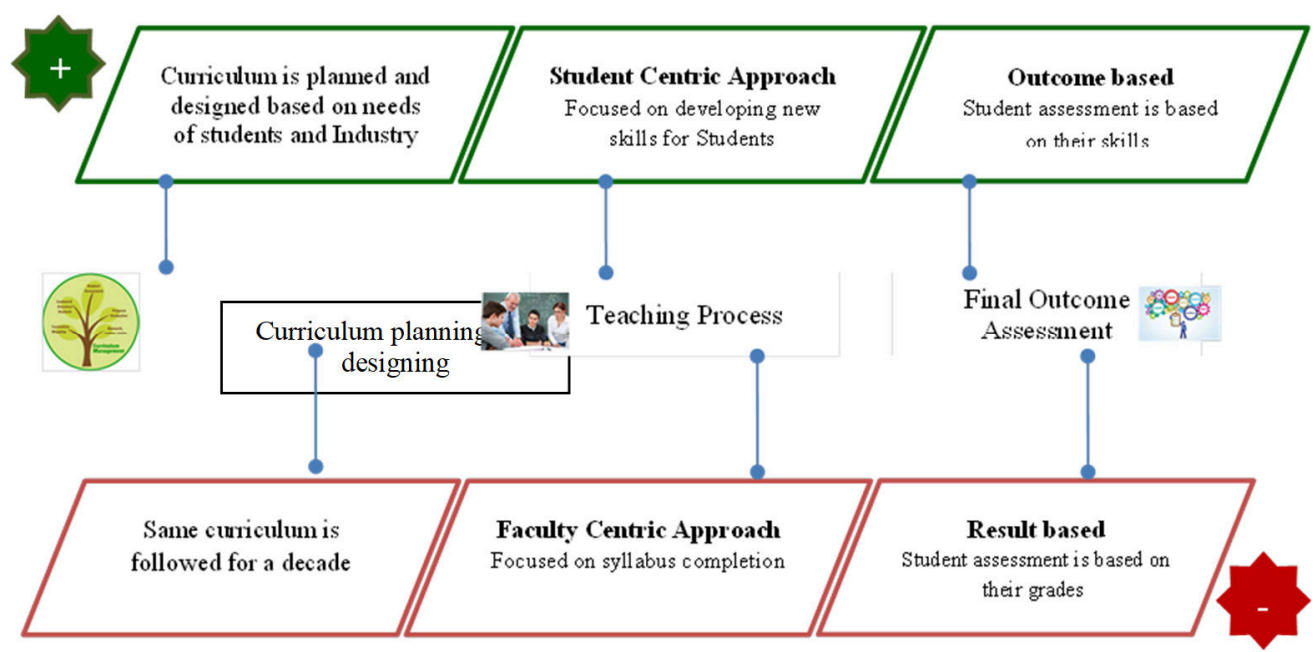

Figure1: Content Based Learning Vs Outcome Based Learning

Program Outcomes (POs) are articulations about the information, abilities and mentalities (traits) the graduate of a program designing system ought to have. POs manage the general part of graduation for a specific program, and the capabilities and ability a graduate will have after fulfillment of the program. NBA has set 12 Program Outcomes or Graduate Attributes for solidarity and quality affirmation. The Program Outcomes set by the institution must echo on these 12 outcomes given by NBA.

Course Outcomes (COs) recognize what the student will know and have the option to do at the completion of a course. COs are stated in such a way that they can be estimated. COs are set by the course handling faculty, course expert and the core committee framed by the department. COs should state clear desires, speak to finishing exhibitions of learning and accomplishment, depict exhibitions that are huge, fundamental, and certain, ideally state just a single factor for an outcome, echo the abrogating standards of value and reasonableness and oblige the requirements of differing students and speak to the insignificant satisfactory degree of execution that a student needs to show so as to be viewed as effective. 


\section{Course Outcome Framing Process}

The Course Outcomes (COs) are framed by course expert in accordance with the bloom's taxonomy and it is checked by the coordinator of the course as shown in figure 2. The COs can be framed by considering the Program Outcomes (POs), Regulations schemes, Program Specific Outcomes (PSOs), exit student survey and stake holders report.

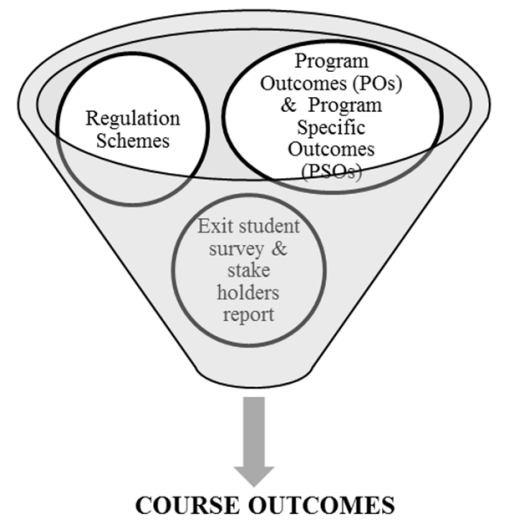

Figure 2: The process of framing Course Outcomes (COs)

Each course in the program consists of four to six course outcomes. The table 2.1 shows the sample Course Outcomes for a course

Table 2.1 Sample Course Outcome

\begin{tabular}{|c|c|c|}
\hline [1] & $\mathrm{CO}$ & Course Outcomes \\
\hline [3] & $\mathrm{CO} 1$ & $\begin{array}{l}\text { [4] Design efficient algorithms by choosing the } \\
\text { appropriate tree data structure and to understand the basic } \\
\text { operations of hashing and collision resolution techniques. }\end{array}$ \\
\hline$[5]$ & $\mathrm{CO} 2$ & $\begin{array}{l}\text { [6] Apply appropriate external sorting algorithms and } \\
\text { priority queue for contemporary applications. }\end{array}$ \\
\hline$[7]$ & $\mathrm{CO} 3$ & $\begin{array}{l}{[8] \text { Understand the properties of disjoint set data }} \\
\text { structure. }\end{array}$ \\
\hline [9] & $\mathrm{CO} 4$ & $\begin{array}{l}{[10] \text { Explore the applicability of various string }} \\
\text { matching techniques for a real world problem. }\end{array}$ \\
\hline [11] & $\mathrm{CO} 5$ & $\begin{array}{l}{[12] \text { To solve problems of connectivity and constraint }} \\
\text { satisfaction, use graph theory models of data structures and } \\
\text { state machines. }\end{array}$ \\
\hline
\end{tabular}

\section{i. Course Outcome - Program Outcome Mapping}

The Program Outcomes and Program Specific Outcomes are mapped as either level 1or level 2 or level 3 with the Course Outcomes of each course which is represented in the matrix form as shown in table 2.2.

Table 2.2 Sample CO-PO mapping for course

\begin{tabular}{|l|l|l|l|l|l|l|l|l|l|l|l|l|l|l|}
\hline \multirow{3}{*}{ COs } & $\mathbf{P}$ & $\mathbf{P}$ & $\mathbf{P}$ & $\mathbf{P}$ & $\mathbf{P}$ & $\mathbf{P}$ & $\mathbf{P}$ & $\mathbf{P}$ & $\mathbf{P}$ & $\mathbf{P}$ & $\mathbf{P}$ & $\mathbf{P}$ & $\mathbf{P S}$ & $\mathbf{P S}$ \\
& $\mathbf{O}$ & $\mathbf{O}$ & $\mathbf{O}$ & $\mathbf{O}$ & $\mathbf{O}$ & $\mathbf{O}$ & $\mathbf{O}$ & $\mathbf{O}$ & $\mathbf{O}$ & $\mathbf{O}$ & $\mathbf{O}$ & $\mathbf{O}$ & $\mathbf{O}$ & $\mathbf{O}$ \\
& $\mathbf{1}$ & $\mathbf{2}$ & $\mathbf{3}$ & $\mathbf{4}$ & $\mathbf{5}$ & $\mathbf{6}$ & $\mathbf{7}$ & $\mathbf{8}$ & $\mathbf{9}$ & $\mathbf{1 0}$ & $\mathbf{1 1}$ & $\mathbf{1 2}$ & $\mathbf{1}$ & $\mathbf{2}$ \\
\hline CO1 & 2 & 3 & 2 & 0 & 0 & 0 & 0 & 0 & 0 & 0 & 0 & 1 & 1 & 0 \\
\hline
\end{tabular}




\begin{tabular}{|l|l|l|l|l|l|l|l|l|l|l|l|l|l|l|}
\hline CO2 & 3 & 2 & 2 & 0 & 0 & 0 & 0 & 0 & 0 & 0 & 0 & 1 & 0 & 0 \\
\hline CO3 & 3 & 2 & 2 & 0 & 0 & 0 & 0 & 0 & 0 & 0 & 0 & 2 & 0 & 1 \\
\hline CO4 & 3 & 2 & 2 & 0 & 0 & 0 & 0 & 0 & 0 & 0 & 0 & 2 & 0 & 1 \\
\hline CO5 & 3 & 2 & 2 & 0 & 0 & 0 & 0 & 0 & 0 & 0 & 0 & 1 & 0 & 0 \\
\hline CO6 & 2 & 2 & 3 & 0 & 0 & 0 & 0 & 0 & 0 & 0 & 0 & 2 & 2 & 0 \\
\hline
\end{tabular}

3 Strong contribution

2 Medium contribution

1 Weak contribution

0 No contribution

\section{Process Of Course Outcome Attainment}

The framing Course Outcomes and mapping them with the Program Outcomes is followed by the assessment of COs. After the delivery of the course to the students, the attainment of COs is assessed by the following direct assessment processes:

- Internal Tests

- Tutorials

- Assignments

- Seminar/Assignment Presentations

- Observation \& Record

- Model Examination

- Project Reviews

- End Semester Examination

Figure 3 represents the process for measuring the attainment of Course Outcome. The student performance is evaluated CO-wise for each course using direct assessment processes and tools. The attainment of COs is calculated by assigning $70 \%$ weight-age to internal assessment and $30 \%$ weight-age to the end semester examination. If the $\mathrm{CO}$ attainment is achieved, the attainment level is increased for the next academic year. If not, appropriate modifications such as additional contact hours, remedial classes, tutorial classes and teaching methodology are identified by Program Assessment Committee (PAC) comprising of Head, Program coordinator, Professors and the same will be applied for next academic year. 


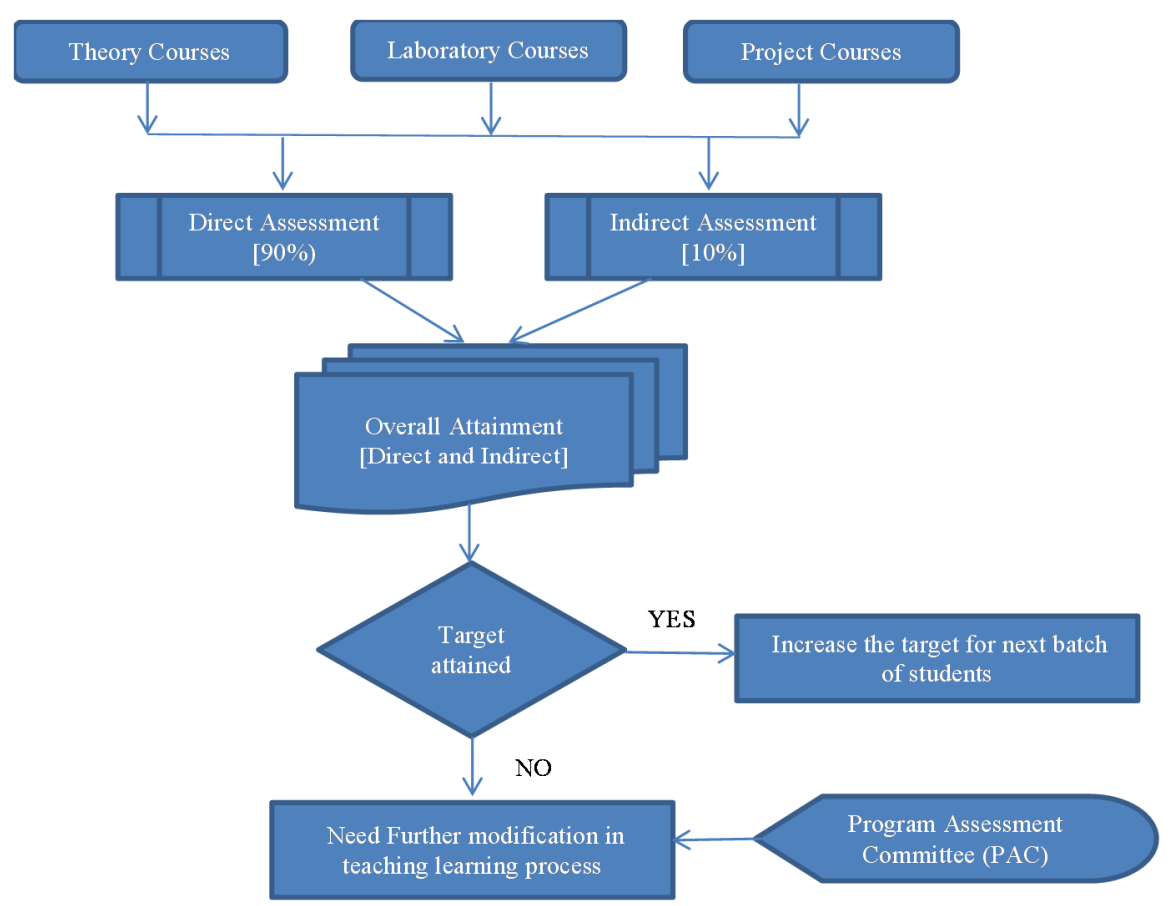

Figure 3. Process for Attainment of COs

The table 2.4 depicts the evaluation scheme for the Course outcome attainment with $50 \%$ weightage for internal assessment and 50\% weightage for end semester assessment

Table 2.4 Evaluation scheme for the Course outcome attainment

\begin{tabular}{|c|c|c|c|c|c|c|}
\hline $\begin{array}{l}\text { Assessment } \\
\text { Tool }\end{array}$ & CO1 & $\mathrm{CO} 2$ & $\mathrm{CO3}$ & $\mathrm{CO} 4$ & $\mathrm{CO5}$ & $\begin{array}{l}\text { \% of } \\
\text { Weightage }\end{array}$ \\
\hline $\begin{array}{l}\text { Internal } \\
\text { test-1 }\end{array}$ & & & & & & \multirow{5}{*}{$50 \%$} \\
\hline $\begin{array}{l}\text { Internal } \\
\text { test-2 }\end{array}$ & & & & & & \\
\hline $\begin{array}{l}\text { Internal } \\
\text { test-3 }\end{array}$ & & & & & & \\
\hline \multirow{2}{*}{\multicolumn{6}{|c|}{$\begin{array}{l}\text { Assignment } \\
\text { Presentation } \\
\text { Tutorial } \\
\end{array}$}} & \\
\hline & & & & & & \\
\hline $\begin{array}{l}\text { End } \\
\text { Semester } \\
\text { Exam } \\
\end{array}$ & & & & & & $\mathbf{5 0} \%$ \\
\hline \multicolumn{6}{|c|}{ Weightage of Direct Assessment } & $90 \%$ \\
\hline \multicolumn{6}{|c|}{$\begin{array}{l}\text { Weightage of Indirect Assessment (Senior Exit } \\
\text { Survey, Employer Survey, Placement Stats) }\end{array}$} & $10 \%$ \\
\hline
\end{tabular}

The attainment of COs is calculated based on the performance of students in direct assessment methods such as serial tests, university examinations, tutorials / assignments, quiz, 
seminar presentation, Observation \& Record, Model Examination, project reviews. The CO attainment of theory courses are obtained through serial tests, university examinations, tutorials/assignments, quiz and seminar presentation. The attainment of COs of Laboratory courses are calculated through Observation / Record and Model Examination. The assessment criteria for attainment of COs in University examination and internal assessments are as follow:

\section{Measuring CO attainment through Internal Assessments: \\ - Attainment Level 1: 60-69\% students scoring more than set target mark \\ - Attainment Level 2: 70-79\% students scoring more than set target mark \\ - Attainment Level 3: Above 79\% students scoring more than set target mark}

\section{Measuring Course Outcomes attained through End Semester Examinations \\ - Attainment Level 1: 60-69\% students scoring more than set target mark \\ - $\quad$ Attainment Level 2: 70-79\% students scoring more than set target mark \\ - Attainment Level 3: Above 79\% students scoring more than set target mark}

The Set target marks may vary for courses. The Program Assessment Committee establishes target marks for each of the corresponding COs in the assessment methods based on the students' previous year's performance. The $\mathrm{CO}$ attainment is calculated for each course by the course instructor and can be documented in their respective course files. The sample Course Outcome attainment sheet is given in the Table 2.5.

The Course target mark is threshold as $70 \%$ in the internal assessment evaluation and number of students achieving the target out of number of students in the class is calculated along with their percentage. The level of attainment is marked as either 1 or 2 or 3 based on the target achieved percentage.

The Course target mark is taken as $60 \%$ in the end semester assessment evaluation and number of students achieving the target out of number of students in the class is calculated along with their percentage. The level of attainment is marked as either 1 or 2 or 3 based on the target achieved percentage. The sample is provided in the table 3.2.

Table 2.5 Sample Course Outcome attainment [Direct Attainment]

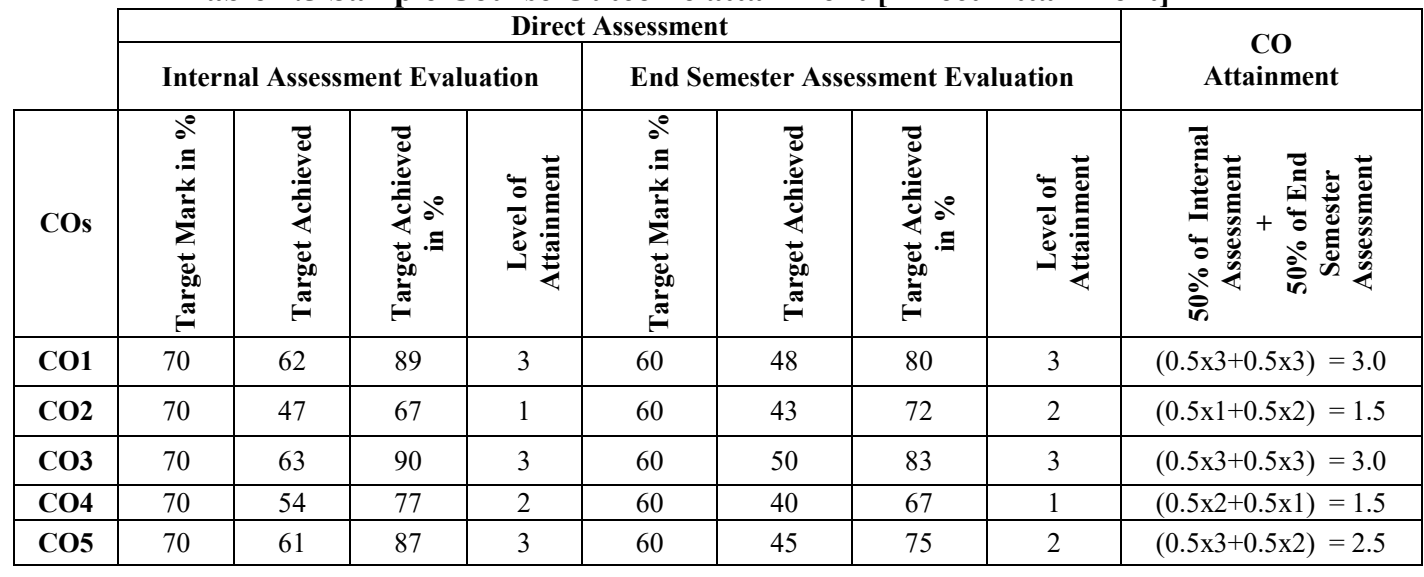


The CO attainment is evaluated as in eqn. 3.1

Co attainment $=70 \%$ of internal assessment $+30 \%$ of End semester assessment ---- (3.1)

For example, if the level of attainment of internal assessment is 3 and the level of attainment of end semester assessment is 2, then $\mathrm{CO}$ attainment is calculated based on eqn. 3.1 and obtained as $(0.5 \times 3+0.5 \times 2)=2.5$. Similarly, the $\mathrm{CO}$ attainment is estimated for the all the courses of the particular programme for the direct assessment of COs.

Table 2.6 represents the overall Course Outcome attainment for the course. The CO attainment calculated so far can be used for direct assessment which is accountable for $90 \%$ and the indirect assessment such as Senior Exit Survey, Employer Survey, and Placement Statistics can be considered for the remaining $10 \%$. The overall attainment is estimated using $90 \%$ of direct assessment and $10 \%$ of indirect assessment for the $\mathrm{CO}$ attainment.

Table 2.6 Overall Course Outcome Attainments

\begin{tabular}{|c|c|c|c|c|c|c|}
\hline [13] & COs & $\begin{array}{l}{[14]} \\
\text { Atta }\end{array}$ & $\begin{array}{l}\text { Direct } \\
\text { nent }\end{array}$ & $\begin{array}{l}{[15]} \\
\text { Atta }\end{array}$ & $\begin{array}{l}\text { Indirect } \\
\text { ent }\end{array}$ & $\begin{array}{l}\text { [16] Overall attainment } \\
{[17] \quad[90 \% \text { of Direct }} \\
\text { attainment and } 10 \% \text { of Indirect } \\
\text { attainment] }\end{array}$ \\
\hline [18] & CO1 & [19] & 3.0 & [20] & 3.0 & $\begin{array}{l}{[21] \quad(0.9 \times 3.0+0.1 \times 3.0)} \\
=3.0\end{array}$ \\
\hline [22] & $\mathrm{CO} 2$ & [23] & 1.5 & [24] & 3.0 & $\begin{array}{ll}{[25]} & (0.9 \times 1.5+0.1 \times 3.0) \\
=1.7 & \end{array}$ \\
\hline [26] & $\mathrm{CO3}$ & [27] & 3.0 & [28] & 3.0 & $\begin{array}{l}{[29] \quad(0.9 \times 3.0+0.1 \times 3.0)} \\
=3.0\end{array}$ \\
\hline$[30]$ & CO4 & [31] & 1.5 & [32] & 3.0 & $\begin{array}{l}\begin{array}{l}{[33]} \\
=1.7\end{array} \quad(0.9 \times 1.5+0.1 \times 3.0) \\
\end{array}$ \\
\hline [34] & $\mathrm{CO5}$ & [35] & 2.5 & [36] & 3.0 & $\begin{array}{l}\begin{array}{l}{[37]} \\
=2.6\end{array} \quad(0.9 \times 2.5+0.1 \times 3.0) \\
\end{array}$ \\
\hline
\end{tabular}

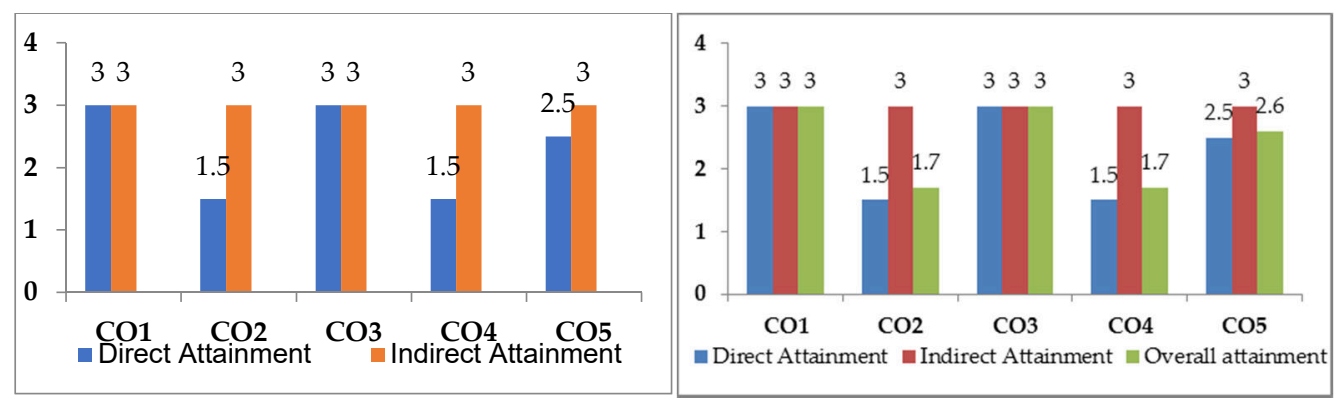

Figure 3. Overall Course Outcome Attainments

Because $\mathrm{CO} 2$ and $\mathrm{CO} 4$ attainment values are below the set targets for those COs, specific measures must be formulated and implemented as part of consistent betterment in the upcoming semester whenever a new batch of students is taught a similar course, and the increase in $\mathrm{CO}$ attainment values should be evaluated and measured. For all other courses in a programme, a similar methodology for calculating $\mathrm{CO}$ attainment must be used, and the values must be recorded separately in attainment matrices 


\section{Conclusion}

Outcome-Based Education focuses and arranges all of it in an educational process across what all students are expected to do in order to succeed at the extreme of their educational experiences. Moving from result based to outcome based clearly improves the abilities of students in problem solving, analytical, research, learning and design. OBE was about how to get better student learning within the available student and faculty, time, funding and other resources. Fixing the target mark is one of the most important aspects of achieving COs. For the purpose of determining the target, the proposed method takes into account the views of majority of stakeholders, including students. Similarly, the CO attainment of all course in the program are calculated and based on the analysis of the attainments of COs, improvements in the teaching learning process can be suggested by the expert team. This work is restricted to $\mathrm{CO}$ attainment which can be used as a parameter for the Program Outcome and Program Educational attainment outcomes. The analysis of these attainment values will aid the programme in incorporating creative approaches to improve the quality of students' performance in successive years as part of continuous improvement.

\section{References}

[1] Washington Accord, Graduate Attributes and Professional Competencies, June 2019. International Engineering Alliance. http://washingtonaccord .org/ illoiance.

[2] Gloria Rogers. ABET (2010) Webinar on Defining Student Outcomes, www.abet.org.

[3] William Spady, "Outcome Based Education - Critical Issues and Answers", American Association of School Administrators.

[4] NBA Website, PPT on Outcome Based Education and Accreditation, http://www.nbaind.org/En/1027-forms-formats.aspx.

[5] National Board of Accreditation Self-Assessment Report (SAR) (From 1st June 2015).

[6] Bloom, B. S.; Engelhart, M. D.; Furst, E. J.; Hill, W. H.; Krathwohl, D. R. (1956). Taxonomy of Educational Objectives: The Classification of Educational Goals. Handbook I: Cognitive domain. New York: David McKay Company.

[7] Dr.Rashid," The Process of Outcome Based Education- Implementation, Assessment And Evaluations,” ASEE International Forum, American Society of Engineering Education, 2013.

[8] V.A.Kulakarni, Ahuja, Dhanvijay ," CO-PO Mapping and Attainment Booklet for Tier II students with Rubrics Assessment," Journal Of Engineering Education Transformation,vol.30,no3,January 2017,ISSN 2349-2473, E- ISSN: 2394-1707

[9] Varsha T. Lokare, Prakash M. Jadhav, "Course Outcomes Attainment for Data Structure Course Using Direct and Indirect Methods", Journal of Engineering Education Transformations, Special Issue, eISSn 2394-1707.

[10] Pragati Sawant, "Course Outcomes Attainment Analysis Using Automated Tool IONCUDOS, Journal of Engineering Education Transformations, Special Issue, eISSN 23941707

[11] M. Tholkapiyan, A.Mohan, Vijayan.D.S , "A survey of recent studieson chlorophyll variation in Indian coastal waters", IOP Conf. Series: Materials Science and Engineering 993 (2020) 012041, doi:10.1088/1757-899X/993/1/012041. 